\title{
DE PIEL Y ARENA; AZOGUE
}

WITH SKIN AND SAND; MERCURY

Piedad Morales 


\section{DE PIEL Y ARENA}

\section{5}

El desierto dejó impresa en piedras bitácora de luz paciencia

La arena nos trae al recuerdo la mar

Los pelícanos con su sonrisa colgante

El olor a selva y a profundidad

La piedra caracol aridez

le dictó al agua las primeras burbujas

y el arquetipo de las ranas

La piel es casa

cobílaba del dolo

Sentimiento erizado

Albergue cierto

Huele

Conoce

Sabe

Respira mezclando-nos

Mapa guarida de ansias anhelos

Complicidad de mucosas

humedeciendo emociones roce

que enuncian marea interior

Ella no miente

Conoce lenguaje de los átomos

y sus incertidumbres

Arena y piel

integran casa templo

en este cuerpo con el que habito el desarraigo

Cueva de mis miedos

Caldero en el que cocino las palabras

Nosotros

Nos creemos los noticiario

La prisa aplaza la risa

El juramento el juego

La mentira al amor

Navegamos por el universo

mortales e indefensos

inocentes y perversos

Nos inventamos lenguajes neutros

Borramos dialectos antiguos

Convidamos al olvido

El perdón se nos ha vuelto un pretexto

convertido en condición divina

De todas maneras somos la esperanza

Junto con pájaros pétalos

Florecemos sal de la creación

Abuelas Tejedoras de Oráculos

Desde épocas remotas tejen el vestido de la descendencia

Prole nómada alegre

Las arrugas son pliegues en la memoria

lunares repiten constelaciones y estrellas

Las abuelas aderezaron en ánfora

Aromas protectoras

Ungüentos sanadores

Hechizos ensoñación

En tiempos de oscura soledad

Pego el oído a la caracola del tiempo

Para escuchar sus canciones

Que me recuerdan el alegre origen

\section{AZOGUE}

"Una no puede decir, sólo se acerca"

MARIA ZAMBRANO

Rosa Fuego

A Sara Rayo, ante su jardín de crespones

Crespón de roja lengua

Perforas las entrañas del silencio

en busca de las palabras

Que

en rictus de ausencia

deletrean soledades

Huso

Conchita de memoria

enquistada en manos

de abuelas Quimbayas

Eco

Recuerdo

humedece de sal

barquito de la infancia

Padre Real

Desmonto el altar en el que te consagré

Intacto e inocent

Rey

Principe

Guardián que nunca estuvo

Para espantar las manos ponzoñosas del abuso

Los azotes del maltrato

Señor del reino de la ausencia

Caricias y palabras tan lejanas

Que no alcanzan este dolor a consolar

La niña sostiene el cántaro que te guarda

Ya no estás intacto

Ya no eres inoce

Funeral de Alas

Tu nectarino aleteo

no logro atravesar

a arena solida

en el ojo del dios que te soñó

Colibri 
Tramador de Claroscuros

Ante una exposición de Omar Rayo

Hombre que trae en el nombre

todo el verde azul preñado de sal y de nostalgia

Califa en el jardín de tu madre

donde te brotaron la risa y los colores

Tu blanco y negro

Incendia el claroscuro del verbo

Enardece las líneas divisorias

Inundas el vacío de laberínticas colchas y carpetas

De cruces con Cristos sin llagas

Jardines con Marías alegres

Revelas las curvas hechas de rectas

Guerrero antiguo y humano

Bajas hasta el andén de las ninfas

A reconciliarte con la vida

Urdimbre Celeste

"Abre la noche sus vitrinas para exhibir sus mercancías"

León de Greeif

El cielo baña con vaho de estrellas

los ribetes del caserío

Un delgado hilo sale del fogón de la aurora

ahumando el despertar de los pájaros

En las casas descansan

mujeres y hombres de esperanza

Apacibles los corazones

Se aprestan a tejer en sueños el canto

A esta hora entiendo las cifras de tu nombre

La Unión

De los seres con sus alegrías y afugias

Con sus ganas de vida digna

Y la matria a cuestas

Vereda la Unión, Comunidad de Paz de San José de Apartadó, Colombia,

Septiembre de 2005

Desertora

Me piden que hable del dolor de patria

Sin embargo se la truequie

a la esperanza por la matria

Sus blasones

Sus himnos y banderas

Pueblan a Colombia de destierro

En las noches violan las niñas

En las mañanas enrolan a los jóvenes

que acuden a matar a otros jóvenes en su nombre

De doler

Me floreciste en las palabras

Cálida Tormenta

Al Ángel de Chocolate

En su enésimo silencio

De donde vienes las mañanas son

oleaje amarillo de trinos y petaladas orugas

Allí la luna es enjambre de mieles y risas

En tardes de nubes lilas se ve un cisne bordear la laguna

De donde vengo

Se agota el rocío

El agua esta salobre

Ardo

Deslizo las manos en laguna de cisne

Y recobro alegría de grano de arena

Entonces no soy mas tiempo ni espera

Ni reloj ni playa

dora de líneas

Desde el Silencio

Llegas mar de caracolas

A recordarle a poros espuma

color de peces y sonido de burbujas

En las manos desde siempre dibujas nuevas líneas

grutas que no van a ninguna parte

Socavas fines y principios

Sin permiso

A mansalva

Saldadas Todas las Culpas

Manchas de mango en bordes de tristeza

Escurridiza alegría en octubre hojeando amarillos

Todos los pájaros rimando con la ausencia

En medio de arco iris

Lágrimas agridulces

Temblor después del desierto

Palabra que no termina de nombrar

Gorjeo que tirita loras y olor a caña

Cuando atravieso

Ciega

Despiert

La humedad que estila tu recuerdo

La Poeta

Siempre creí que el poema

haría inmortal mi carne

- Estas palabras se cocinan en la misma fogata del infinito

donde Platón trata eternamente de rescatar las suyas-

De qué voy a hablar

Sin alma

El espíritu siempre dilatado

Dis-traído

Disperso

El odio me hace humana

La risa niña

Mujer el dolor

La ira desobediente

Resiste-ante

La alegría

La poesía tal vez

Solo

Tal vez

Sostenga vi

ga viva la enamorada

enancia 
Sombra

Pasos en noche de grillos

Sollozo contenido

Inútil muerte

Lágrimas de amor imposible

Trampas

... Corriente arriba

Saliva...

Fluido amoroso

En días de malos presagios

-noches de guerra-

Declarar huelga

Llevan presa la alegría!

A liberar atardeceres

Aunemos voces para cantar

Canciones de ternura

Alborozos...

¡A liberar la alegría!

Alguna Vez Penumbra

Las manos se soltaron de las tuyas

Viajaron

piel

deseo

Caminos sembrados de soledad

Al fondo del abismo

esperaba agua de nacimiento

Húmeda

ahíta de silencio

la mañana espera

arrullando

arrullando en el pecho

olvidos

Las aristas

en senderos de regreso

marcan señales

recolectan sabores

Aguardo

Las heridas serán flores disecadas

Reposando en el jardín de las vejeces

Insumisa

A, Antígona: Princesa griega,

hija de Edipo y Yocasta

Afloró de niña a lazarillo

Muchacha jugosa

se supo carne de extermini

Desobedeció al loco

promulgador de leyes y sentencias

Despacio se dispone

a despedir al hermano

Besa sus ojos

Le canta una nana dulce

Al alba

Un tropel en la sangre

augura frío

Mujer Con Escoba Y Niño
Barres de dentro para fuera

Espantas sanguijuelas

y malos pensamientos

Un niño sube y baja de tus brazos

mientras intentas

limpiar dolor y olvido

de los andenes de la patria

América Viuda

A Talauula, princesa de la alegría,

en el reino de Abyala.

Me llega un rumor de alerta tempran

En el pantano se ahoga el príncipe

ahíto de gritos y cuerpos sin nombre

Él se hizo un abrigo de diminutas flores

Juntó néctar con libaciones

para

Con el beso

diluirlas en mi sangre

Yo urdí esta falda de mangla

ensayé este jolgorio de loras

Me perfume de alba y hoja

Hoy oro por su alma

abrazada a este hombre

cuya única señal particula

es una diminuta flor

enquistada en 